\section{Panofkas stambog}

at furstebibliotek ar Niels Krabhe. I) t Kongellige Billiontek.

$\mathrm{P}$ anofkas stambogr (mu 72(15.10)14) er et af Musik- (og Teaterafdelingens fineste manuskripter. Stambogen blev kobt af biblioteket i 1972 og foreligger nu som gennemkommenteret faksimileudgave, udgivet af den tidligere leder af Musikafdelingen, furstebiblistekar Fva-Brit Fanger pa H.ans Schneider V'erlag i Tutzing. Efter kobet i 19) 2 viede Fra-Brit Fanger en meget stor del af sin fritid - dels gennem alle arene sem ansat pa $\mathrm{KB}$, dels i de efterfolgende ar som pensioneret til en minutios gennemforskning af dette interessante manuskript, der ved forste (ijekast fremstod som nogret af en udfordring: Hvem var Panofka? Hrad blev der af stambogen efter at Panofka var holdt op med at interessere sig for den? Hvad var det for rarker eller brudityker af varker, de mere end sil komponister havde indfort i stambogen? Hvilken musihhistorisk interesse havde stambogen i ovrigt?

Disie og mange andre sporgemal er forsengt bess aret i Eva-Brit Fangers omfattende kommentarer til faksimileudgaren, der orerordnet tegner et intereasant billede af et lille hiorne af det 1\%. arhundredes europ.ciste musikhistoric.
$\mathrm{H}$ einrich Panofka (18(1)?-1887) var tysk violinist, senere sangpxdagrog, og i mindre grad komponist. I de to forste egenskaber - ikke mindst som omrejsende virtuos - havde han et vist narn i sin samtid, men havde det ikke varet for de sporr han har efterladt sig i form denne stambog, harde nxppe nogen i eftertiden fundet det ulejligheden vard at beskxftige sigr med ham.

Stamboger var forholdswis almindelige i forste halvdel af $18(1)()$-tallet. Den rejsende kunstner eller skonand indsamlede undervejs hilsner i form af "gode ord", digte, kloge rad, eller - som i Panofkas tilfælde - musikfragmenter. Hvis ejeren af stambogen var tilstrakkelig beromt, var det vel en wre at fa low at skrive i bogen; var det derimod den skrivende, der var den beromte, var det en xre for ejeren af bogen at modtage hans hilsen. Panofkas stambogr har eksempler pa begge dele.

Det, der gror netop denne stambog interessant, er dels, at der er tale om en ren nodebogr (med to) undtagelser er der udelukkende musikalske hilsner i bogen), dels at der blandt de mange indforsler er autografer af $1801(1-t a l l e t s$ ubetinget ment betrdelige europxiske komponister. Hertil skal fojes, at visee af indforslerne - dong fortrineris af de mere ukendte mushere og komponister - udelukhende hendes fra Panofka; at de altsa er uniha. Kt af Fira-Brit Fangers anliggender med sine undersengelecer, der gennem arene medforte rejeer ul aleerden biblenteher og arkiser, var neterp at hlarlaggere disse 


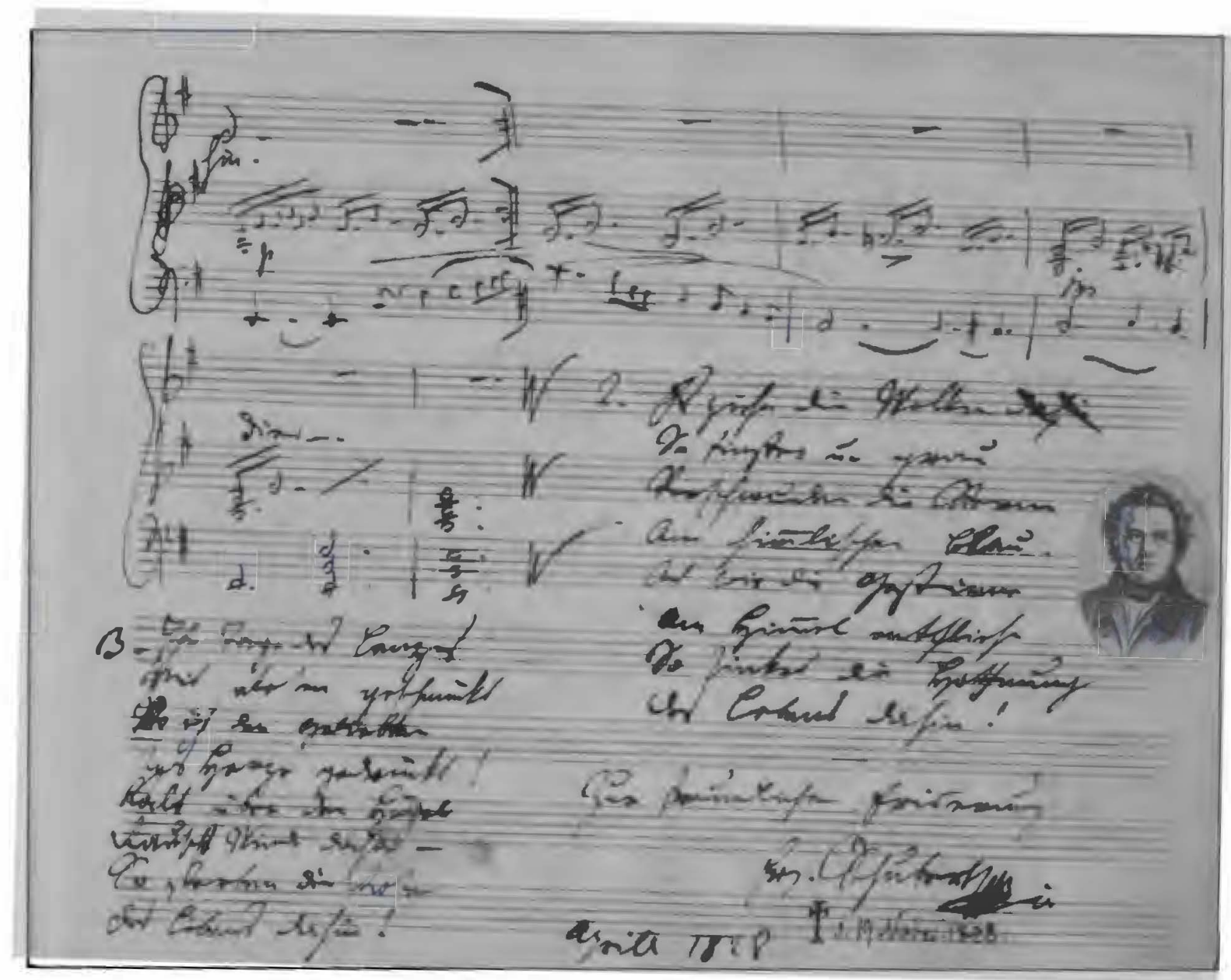

Sidste side of Schuberts lied Herbst til tekst af Rellstab. Panofkas stambog er den eneste bet'arede kilde $i$ Schuberts bind til denne lied. Afsluttende bar Sibubert tilfojet en personlig bilsen til Panofka: "Zur freundlichen Erinnerung. Fri. Schubert" (Det Kongelige Bibliotek).

proveniens-forhold så noje som overhovedet muligt.

Stambogen indeholder to lag af meget forskellig karakter. Forste lag - og i alt væsentligt forste del af bogen - består af indforsler fra perioden 18271843, alle stilet til Panofka. Herefter synes han at have mistet interessen for bogen - eller måske har han ikke fået den med sig, når han rejste omkring - og i 1866 skilte han sig definitivt af med den. Med dette år indledes bogens andet lag, nemlig de indforsler, som den nye ejermand, Panofkas sangelev, amerikaneren Alfred C. Clark, foranledigede.
Panofka overdrog ligefrem stambogen til Clark med dedikation: "Offerte à son cher elève et ami / Alfred C. Clark / en témoignage d'estime et d'affection / H.Panofka / Paris le 8 Mars 1866". Clark tog bogen med sig til Amerika og siden til Norge, hvilket afspejler sig i en række nordiske - også danske - indforsler fra sidste del af àrhundredet. Indforslerne i Clarks tid er mindre personlige og mindre hjertelige end de, der var rettet til Panofka. Bogen skifter som antydet karakter fra at være et udtryk for gode relationer og venskaber til at blive en egentlig autografsamling. 


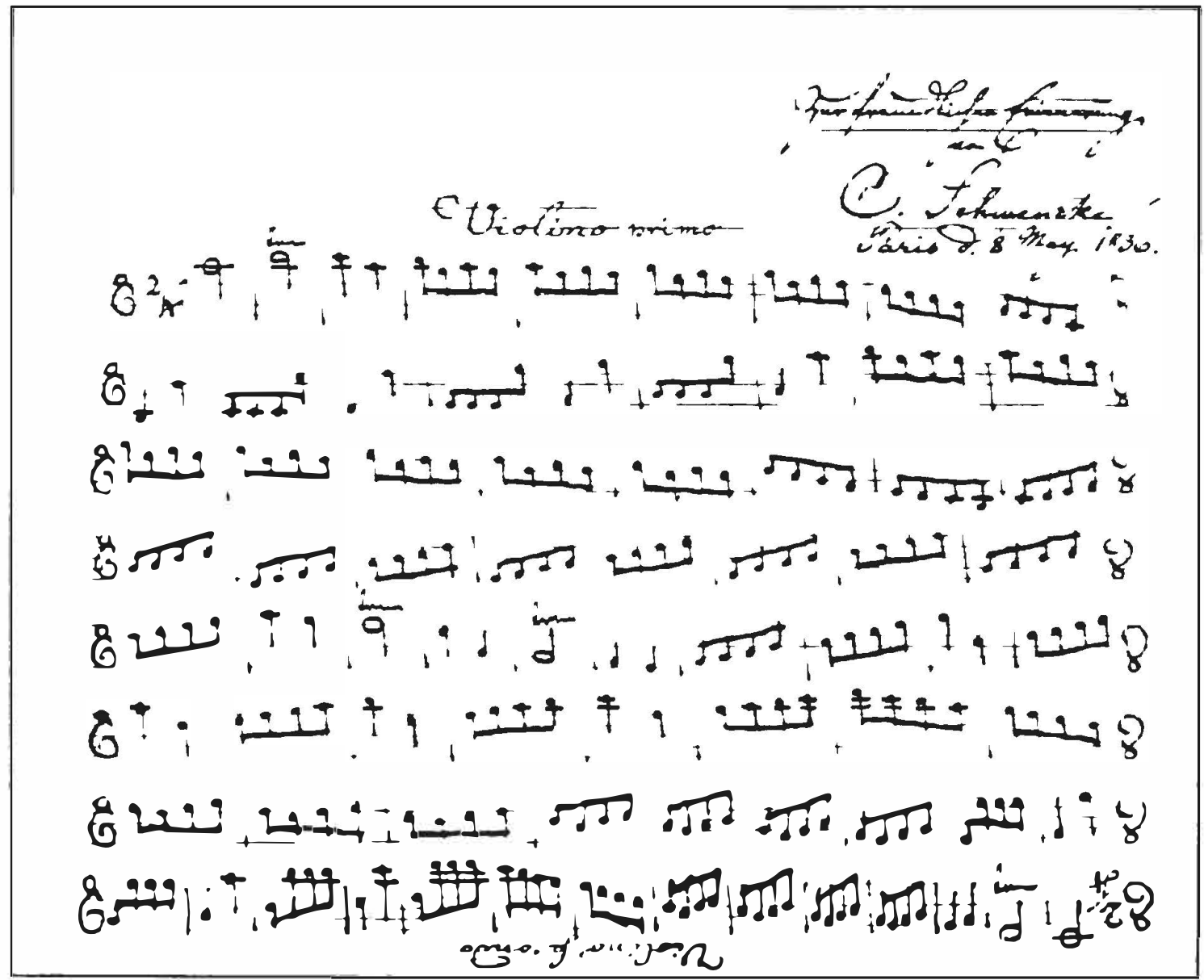

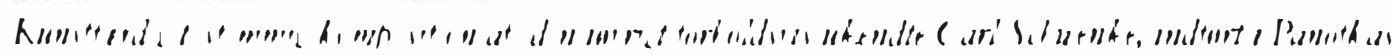

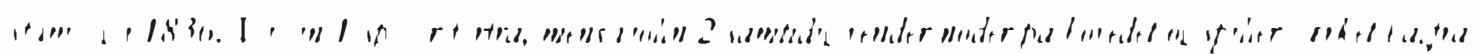

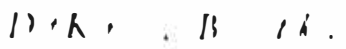

la forrhellige onseje kom

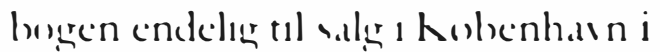

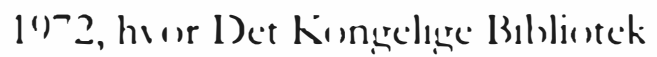
pal a a Brit l angers fordanledninger hecrededen.

1) mere end sill reprexenterede hem ponester han grost epdeles a tre hosed hategremer:

- 1)e helt store meentre Becethosen, Berlans, Brahme, Ist/t, Morart, Schulere, Sichumann we lleler

- Samedenehende homponister, stem eftertalen don har placeret uden fier hredeen af de aboshlut sterste \.ll. (iacke, J.P.I:. H.artm.ınn, J.\. Hummel,
Fran, Lachner, lyan, Mocheles, Paranini, . Inton Rubinstein, Spon tini, Joh.ın Sicenden, Gunn.ır llien nerberes

- Lit hredt udenit af tedene hleinmea stere, som 1 dager tortalt uhendte f.ehs. Hllere, Buhm, (iomes, I.cenau, Morralt, Rolla, Siarma, Strune os It urtil, for blot at now ne noske uranuhe tid.

Badrazence at mezet fier shellie art; her er fuldt fierdien hempor ettener, fia tahtere citater frat torseken hendte s.erher, undrige hentrapunhershe

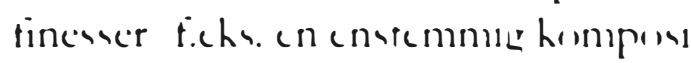

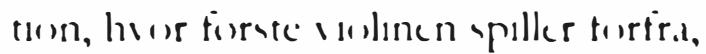


mens anden violinen samtidig vender noden på hovedet og spiller det samme - næsten i omvending - bagfra), losrevne enkeltstemmer fra storre værker eller slet og ret fire toner (G-A-D-E)!

Som egentlig kilde til det 19. århundredes musik har Panofka således kun mindre interesse; meget få af kompositionerne er interessante i sig selv, og hvis de er det, kendes de som oftest allerede i forvejen. Faktisk er det kun to af indforslerne, der virkelig påkalder sig interesse som musikalske kilder, men de er til gengæld også yderst vigtige. Den ene er stambogens allerforste bidrag, en indklistret side med ombukkede kanter, beskrevet på begge sider med Beethovens karakteristiske - og nærmest ulæselige - håndskrift. Her er tale om en skitse eller en tidlig version af en halv snes takter fra sidste sats af Beethovens cis mol strygekvartet opus 131 - unægtelig et af kvartetlitteraturens hovedværker. Beethoven var doende, da Panofka påbegyndte indsamlingen til sin stambog, og skitsebladet modtog han - med en påskreven bekræftelse på dets ægthed - fra Beethovens nære medarbejder, Anton Schindler, med en datering tre dage for Beethovens dod.

Stambogens anden indforsel, der i sig selv udgor en vigtig musikhistorisk kilde (faktisk stambogens vigtigste), er Franz Schuberts lied Herz til tekst af Ludwig Rellstab, indfort i sin fulde længde med sang- og klaverstemme og den komplette tekst, alt sammen i Schuberts egen hånd, med hilsen til Panofka dateret "april 1828", kun godt 6 mảneder for Schuberts dod i november samme år. Panofka-versionen er faktisk den eneste bevarede version af denne lied i Schuberts egen hånd, $\mathrm{og} \mathrm{da}$ Brahms mere end 50 år senere fik Panofkas stambog i hænderne, gennembladede han bogen og stodte på Schuberts lied, som han ojeblikkelig kopierede. Denne kopi af Brahms blev herefter anvendt, da sangen senere skulle udgives for forste gang.

Selvom de fleste af værkerne, som nævnt ovenfor, er knap så interessante når de betragtes som enkeltstående musikværker, giver Panofkas stambog et yderst levende billede af tidens gængse genrer og musikalske stil, og den tegner et billede af et musikalsk miljo, som man er tilbojelig til at overse, når man udelukkende beskæftiger sig med de kanoniserede mesterværker af de anerkendt "store" komponister. Samtidig bidrager stambogen - forst og fremmest selve "Panofka-delen" - til en beskrivelse af en enkelt musikers færden og præferencer, alt sammen kortlagt gennem Eva-Brit Fangers ihærdige detektivarbejde gennem mere end 20 àr, hvor hun som en del af arbejdet să at sige har rejst i Panofkas fodspor.

$\mathrm{P}$ å bibliotekets hjemmeside har man i mange år kunnet se eksempler fra stambogen, og afdelingen har lobende modtaget henvendelser fra udenlandske forskere omkring enkeltindforsler i bogen. Denne faksimileudgave med tilhorende kommentarer og musikhistorisk indledning vil - sammen med en forhảbentlig fremtidig digitalisering af hele stambogen - oge kendskabet til denne særprægede kilde til det 19 . århundredes musikhistorie. 